\title{
MODEL PENYULUHAN KB BERBASIS GENDER DALAM MENCEGAH KEKERASAN DALAM RUMAH TANGGA DI KABUPATEN PURBALINGGA
}

\author{
Dyah Retna Puspita, Rin Rostikawati, dan Lilis SS \\ Fakultas Ilmu Sosial dan Ilmu Politik Universitas Jenderal Soedirman \\ email: dyahrpuspita@yahoo.com
}

\begin{abstract}
This study was conducted in Purbalingga which has a lot of hair manufacturing company which are predominantly done by women. The aims of this research were: (1) to analyze the phenomena of shifting of gender role in labor families, (2) to analyze the implementation of family planning counseling as a prevention of domestic violence, and (3) to create a gender-based family planning model to prevent it. The result shows that (1) there is a shifting of gender role in research location, (2) the activity of domestic violence counseling was rarely implemented, and (3) revitalization of those counseling model involving strategy, target and counseling materials need to be implemented.
\end{abstract}

Key words : family planning extension shifting gender role, domestic violence and dissemination on gender basic.

\begin{abstract}
Abstrak
Penelitian ini dilaksanakan di Purbalingga yang memiliki banyak perusahaan pengolahan rambut yang mayoritas pekerjanya adalah perempuan. Tujuan penelitiannya adalah: (1) mengkaji fenomena alih peran gender dalam keluarga di kalangan pekerja perusahaan rambut; (2) mengkaji pelaksanaan penyuluhan dalam mencegah terjadinya Kekerasan dalam Rumah Tangga (KDRT); (3) mendesain model penyuluhan berbasis gender dalam mencegah KDRT. Hasil penelitian menunjukkan bahwa: (1) fenomena alih peran gender memang terjadi; (2) penyuluhan pencegahan KDRT masih jarang dilaksanakan dan (3) diperlukan revitalisasi model penyuluhan KDRT yang menyangkut strategi, sasaran dan materi penyuluhannya.
\end{abstract}

Kata kunci: alih peran gender, kekerasan dalam rumah tangga dan penyuluhan berbasis gender.

Pendahuluan

Undang-undang Nomor 52 Tahun 2009 tentang Perkembangan Kependudukan dan Pembangunan Keluarga, Pasal 1 mengatur bahwa pembangunan keluarga adalah upaya mewujudkan keluarga berkualitas yang hidup dalam lingkungan yang sehat. Pembangunan bidang ini perlu diprioritaskan karena keluarga merupakan inti dari sebuah masyarakat dan mempunyai sejumlah fungsi strategis yang tidak dapat digantikan oleh lembaga lain.

Salah satu permasalahan keluarga yang terjadi di masyarakat saat ini adalah pergeseran peran gender dalam keluarga di mana istri yang lebih berperan sebagai pencari nafkah utama.

$\Omega \quad$ Tulisan ini merupakan hasil penelitian dengan Surat Perjanjian Pelaksanaan Penelitian Unggulan PT Nomor 2742.19/UN23.10/PN/2013
Kecenderungan ini antara lain terjadi di Kabupaten Purbalingga, Provinsi Jawa Tengah terkait dengan banyaknya perusahaan rambut (bulu mata dan rambut palsu/wig) kebanyakan investornya berasal dari China dan Korea Selatan.

Hampir $90 \%$ pekerja perusahaan tersebut adalah perempuan. Ketidakseimbangan lapangan pekerjaan ini menyebabkan terjadinya kecenderungan pengangguran di kalangan laki-laki yang lebih tinggi dibandingkan perempuan. Hal ini diduga melahirkan fenomena pergeseran peran gender dalam keluarga di mana istrilah yang lebih dominan secara ekonomi dibandingkan suami.

Kemunculan fenomena alih peran gender dalam keluarga tersebut seiring dengan meningkatnya kasus perceraian dan kekerasan dalam 
rumah tangga (KDRT) pada beberapa tahun terakhir. Kondisi ini menunjukkan ketahanan keluarga di Kabupaten Purbalingga cenderung lemah. Mengingat keluarga adalah inti dari suatu masyarakat dan merupakan sumberdaya yang di butuhkan untuk pembangunan, maka fenomena ini perlu dikaji agar dapat diupayakan solusinya.

Badan Keluarga Berencana dan Pemberdayaan Perempuan (BKBPP) Kabupaten/Kota merupakan lembaga yang dibentuk sebagai implykasi desentralisasi program KB. BKBPP Kabupaten Purbalingga dibentuk dengan misi: mewujudkan pembangunan yang berwawasan kependudukan dan mewujudkan keluarga kecil bahagia dan sejahtera, serta mewujudkan kebijakan yang responsif gender dan peduli anak untuk meningkatkan kualitas hidup dan perempuan serta memenuhi hak tumbuh kembang dan perlindungan anak dari kekerasan. Salah satu fungsinya adalah menyelenggarakan penyuluhan di bidang KB dan Pemberdayaan Perempuan.

Lembaga tersebut sangat terkait dengan pembangunan keluarga. Termasuk di dalam pembangunan keluarga ini adalah penghapusan KDRT yang juga merupakan amanah Undang-undang Nomor 23 Tahun 2004 tentang Penghapusan Kekerasan dalam Rumah Tangga. Penelitian ini, oleh karenya mengkaji sejauh mana responsivitas gender penyuluhan KB yang dilaksanakan dalam upaya mengatasi permasalahan dan memenuhi kebutuhan keluarga setempat. Dalam kondisi di mana pada umumnya alokasi program pemberdayaan keluarga sangat terbatas, maka pendekatan penyuluhan berperspektif gender ini perlu diterapkan agar hasilnya optimal.

\section{Permasalahan}

Penelitian ini bermaksud: mengkaji fenomena alih peran gender dalam keluarga di Purbalingga, mengkaji pelaksanaan penyuluhan KB dalam mencegah KDRT dan merancang model penyuluhan KB berbasis gender dalam mencegah KDRT dalam upaya meningkatkan ketahanan keluarga.

\section{Metode Penelitian}

Penelitian ini dilaksanakan di Kabupaten Purbalingga khususnya di empat kecamatan (Ke- camatan Purbalingga, Kalimanah, Bojongsari dan Padamara) yang banyak berdiri perusahaan rambut yang menyerap ribuan pekerja perempuan, terutama yang berasal dari warga di lingkungan tersebut. Hal inilah yang diduga memunculkan fenomena alih peran gender dalam keluarga. Informan utama penelitian ini adalah 48 Kader KB dan kesehatan Desa di ke-4 kecamatan tersebut. Para perempuan pekerja sosial ini pada umumnya telah bekerja lebih dari lima tahun, sehingga mengenal kondisi keluarga di wilayah mereka.

Informan pendukungnya adalah para pejabat BKBPP dan instansi lain yang terkait, Penyuluh $K B(P K B)$, serta sejumlah keluarga yang istrinya bekerja di perusahaan rambut. Data dikumpulkan melalui wawancara mendalam, diskusi terarah, pengamatan dan studi dokumentasi, selanjutnya, data dianalisis menggunakan model analisis interaktif. Validitas data penelitian ditempuh dengan cara triangulasi.

\section{Pembahasan}

\section{Fenomena Alih Peran Gender dalam Keluarga di Lokasi Penelitian}

Ketentuan Pasal 31 Undang-undang Nomor 1 Tahun 1974 tentang Perkawinan mengatur bahwa suami adalah kepala keluarga dan istri adalah ibu rumah tangga, selanjutnya pada $\mathrm{Pa}$ sal 34 diatur bahwa suami wajib melindungi segala sesuatu keperluan hidup berumah tangga sesuai dengan kemampuannya. Istri wajib mengatur urusan rumah tangga sebaik-baiknya. Rumusan ini pada umumnya dipahami bahwa suamilah yang menjadi pencari nafkah utama, sedangkan seandainya istri bekerja, maka sifatnya hanya sebagai pendukung.

Kenyataannya, pembagian peran gender dalam keluarga tersebut saat ini di Purbalingga cenderung mulai lentur dan beralih di mana istrilah yang lebih dominan secara ekonomi, sementara suami menjadi pencari nafkah tambahan. Hal ini terjadi seiring dengan banyaknya perusahaan rambut yang berdiri di kota ini yang menyerap ribuan pekerja perempuan. Semakin banyaknya keluarga dengan pola "ba-ru" ini menyebabkan muncul istilah lokal yang mulai banyak dikenal yakni "pamong praja" yang meru- 
pakan plesetan dari "papa momong mama kerja” (bapak mengasuh anak, ibu bekerja).

Hasil wawancara dan diskusi kelompok terarah dengan para Kader yang didukung dengan wawancara terhadap sejumlah keluarga "pamong praja" menunjukkan bahwa fenomena "pamong praja" memang terjadi di wilayah mereka meskipun tidak diketahui secara pasti jumlahnya. Paling tidak, di satu wilayah Rukun Warga (RW) dapat dijumpai sekitar 10-25 keluarga yang menerapkan pola tersebut. Para istri pada umumnya bekerja di perusahaan rambut (dikenal dengan sebutan "PT"), sedangkan suami bekerja serabutan atau bahkan menganggur. Kebanyakan mereka bekerja sebagai petani, tukang bangunan, supir, tukang becak dan makelar. Tidak sedikit pula yang nyaris tidak bekerja sama sekali, sehingga dengan demikian mereka lebih mempunyai waktu di rumah untuk mengasuh anak dan mengurus rumah tangga

Berdasarkan tipe pekerjaan suami tersebut, penghasilan mereka menjadi tidak menentu dan pada umumnya lebih sedikit dari penghasilan istri yang minimal sama dengan ketentuan Upah Minimal Kabupaten (UMK) sebesar Rp.896. $500,-$, bahkan jika mereka rajin kerja lembur (di bawa ke rumah maupun dikerjakan di perusahaan), maka upahnya bisa mencapai Rp.1.500.000 atau bahkan lebih. Hal ini semakin memperkuat gambaran adanya alih peran gender di mana istrilah yang lebih dominan secara ekonomi.

Waktu luang suami yang lebih banyak memungkinkan sebagian dari mereka mau mengerjakan pekerjaan domestik seperti mencuci dan menjemur baju serta mengantar anak ke sekolah. Mereka biasanya juga mengantar dan menjemput istri bekerja, sehingga dikenal istilah suami adalah "tukang ojek istri". Muncul pula plesetan "ternak teri" (nganter anak nganter istri) yang berarti mengantar anak dan istri. Adapun untuk pengasuhan anak biasanya ditangani ibu/ ibu mertua. Tidak sedikit pula suami yang lebih banyak melakukan kegiatan non-produktif seperti mengobrol dengan teman-teman, bermain bola serta memancing.

Dominannya istri dalam keluarga juga ditemui pada keluarga nelayan sebagaimana dite- mukan dalam kajian Retno Andriati. ${ }^{1}$ Keadaan lingkungan alam yang tidak pasti berpengaruh terhadap konstruksi jender pada masyarakat nelayan. Dalam hal ini, secara emic, tidak ada ketimpangan jender, karena tidak ada perubahan sikap dan perilaku atau peran suami sebagai nelayan dan istri sebagai istri nelayan. Pembagian kerja ini sifatnya turun temurun, tanpa protes istri terhadap suami dan masyarakatnya. Namun secara etic terdapat ketimpangan jender, karena istri harus bertanggungjawab terhadap pemenuhan kebutuhan sosial ekonomi rumah tangga nelayan.

Berdasarkan hasil kajian Rani Andriani Budi Kusumo dkk. menunjukan bahwa meski nelayan perempuan (istri nelayan) berperan penting dalam kegiatan pernelayanan, akan tetapi pada umumnya mereka tetap menganggap bahwa tugas utama istri adalah mengurus rumah tangga, tetapi boleh membantu suami dalam mencari nafkah keluarga, sedangkan tanggung jawab mencari nafkah utama tetap merupakan tugas suami. ${ }^{2}$ Fenomena dominannya istri juga dapat ditemui dari hasil penelitian Cakrawala Timur 2004 sebagaimana dikutip Mustain Mashud yang menunjukkan hampir $75 \%$ perempuan di Jawa Timur menjadi tumpuan ekonomi keluarga. Para ibu rumah tangga ini terpaksa bekerja karena tekanan kemiskinan di desanya. Mengingat sumber ekonomi pertanian di desa kurang menjanjikan, pilihan utama dan pertama mereka adalah menjadi buruh migran, termasuk migrasi internasional, menjadi TKW. ${ }^{3}$

Hasil penelitian Tri utami, dkk di kalangan nelayan di Pangandaran menunjukkan hasil senada. Kontribusi istri nelayan bagi kehidupan keluarga mereka besar dengan curahan waktu kerja tertinggi pada aktivitas produktif ekonomi

1 Retno Andriati, “Relasi kekuasaan Suami dan Istri pada Masyarakat Nelayan", Jurnal Masyarakat Kebudayaan Politik, Vol. 21 No. 1, 2010, Surabaya: FISIP Universitas Airlangga, hlm. 50-58.

2 Rani Andriani Budi Kusumo, Anne Charina, Gema Wibawa Mukti, "Analisis Gender dalam Kehidupan Nelayan di Kecamatan Pengandaran Kabupaten Ciamis", Jurnal Social Economic of Agriculture, Vol. 2, No. 1, April 2013, Pontianak: Fakultas Pertanian Universitas Tanjungpura, hlm. 42-53.

3 Mustain Mashud, "Perspektif Fenomenologi tentang Trafficking TKW", Jurnal Masyarakat Kebudayaan dan Politik, Vol. 21 No. 2, Tahun 2010, Surabaya: FISIP Universitas Airlangga, hlm. 146-154. 
sekitar 9 jam. Pengambilan keputusan rumah tangga dilakukan secara demokratis dengan didominasi oleh istri nelayan pada pengambilan keputusan dalam hal kebutuhan pangan yaitu sebesar $90 \%$ dari tingkat keputusan dan pembelian alat rumah tangga sebesar 100 persen dari tingkat keputusan. ${ }^{4}$ Temuan senada juga terjadi di kalangan nelayan di Bedono. ${ }^{5}$

Hasil wawancara dan diskusi terarah dengan para kader menunjukkan bahwa tidak sedikit istri yang sering mengeluh kepada kader tentang kondisi keluarga mereka. Keluhan yang biasanya dilontarkan adalah rasa capai karena bekerja seharian (dari jam 8 - sekitar jam 17) dan terkadang masih harus mengerjakannya di rumah. Tidak sedikit pula yang masih harus mengerjakan pekerjaan rumah tangga sebelum atau sesudah berangkat seperti menyiapkan keperluan anak, menyeterika dan sebagainya. Hal ini terkadang berdampak pada pelayanan hubungan intim suami-istri di mana tidak jarang istri menolaknya dengan alasan capai. Kalaupun mau melayani, terkadang dengan kondisi psikis yang tidak mood atau bahkan terpaksa.

Keluhan lainnya adalah kurangnya keterlibatan suami dalam urusan rumah tangga (bahkan tidak sedikit yang cenderung tidak perhatian) serta kurang gigihnya suami untuk mencari kerja yang lebih baik. Jumlah anak antara 1-3 orang dan dengan tuntutan hidup yang semakin tinggi, seringkali mendorong istri meminta suami untuk mencari kerja yang lebih baik.

Tidak jarang mereka harus meminjam uang kepada orang tua, saudara atau meminjam di koperasi "PT" untuk menutupi kebutuhan baik yang bersifat harian/rutin maupun insidental (misalnya untuk menyekolahkan anak, berobat dan sebagainya). Permintaan istri ini, terkadang ditanggapi secara dingin oleh suami atau bahkan

4 Trie Utami Akbarini, Iwang Gumilar, Roffi Grandiosa, “Kontribusi Ekonomi Produktif Wanita Nelayan terhadap Pendapatan Keluarga Nelayan di Pangandaran, Kabupaten Ciamis", Jurnal Perikanan Kelautan, Vol. 3 No.3, tersedia di website http://jurnal.unpad.ac.id/jpk/article/view/1421, diakses tanggal 22 Juli 2014.

Wahyu Nugraheni S, Tri Marhaeni PA, Sucihatiningsih DWP, "Peran dan Potensi Wanita dalam Pemenuhan Kebutuhan Ekonomi Keluarga Nelayan". Journal of Educational Social Studies Vol. 1 No 2, Tahun 2012, tersedia di http://journal.unnes.ac.id/sju/index.php/jess/article/view/739, diakses: 25 Juli 2014. dengan mengeluarkan perkataan dan atau sikap yang menyakitkan seperti membentak atau marah.

Berbagai kondisi tersebut rentan menimbulkan masalah kekerasan dalam rumah tangga yang terutama berupa kekerasan psikis dan seksual. Hal ini pada akhirnya dapat berdampak pada munculnya kasus perselingkuhan maupun perceraian. Beberapa informan mengatakan bahwa di wilayahnya ada beberapa kasus perselingkuhan baik yang dilakukan oleh istri maupun suami. Ditemui pula beberapa kasus perceraian.

Kerentanan terjadinya KDRT pada keluarga yang posisi suami lebih rendah dari istri (antara lain dalam status ekonomi) juga ditemukan dalam kajian Babcock, dkk. ${ }^{6}$ Hal ini menunjukkan betapa pentingnya konseling keluarga. ${ }^{7}$

Ketentuan Pasal 1 Undang-undang Nomor 23 Tahun 2004 tentang Penghapusan Kekerasan dalam Rumah Tangga, Kekerasan dalam Rumah Tangga adalah setiap perbuatan terhadap seseorang terutama perempuan, yang berakibat timbulnya kesengsaraan atau penderitaan secara fisik, seksual, psikologis, dan/atau penelantaran rumah tangga termasuk ancaman untuk melakukan perbuatan, pemaksaan, atau perampasan kemerdekaan secara melawan hukum dalam lingkup rumahtangga. Kekerasan psikis adalah perbuatan yang mengakibatkan ketakutan, hilangnya rasa percaya diri, hilangnya kemampuan untuk bertindak, rasa tidak berdaya dan/ penderitaan psikis berat pada seseorang. Kekerasan seksual adalah pemaksaan hubungan yang dilakukan terhadap orang yang menetap dalam lingkup rumah tangga tersebut.

\section{Pelaksanaan Penyuluhan Pencegahan KDRT}

Kader KB Desa/Kelurahan adalah tenaga sukarela/sosial yang membantu Penyuluh KB (PKB) yang merupakan petugas penyuluh formal

\footnotetext{
Babcock, dkk, "Power and violence: The relation between communication patterns, power discrepancies, and domestic violence", Journal of Consulting and Clinical Psychology, Vol. 61 No. 1, Februari 1993, hlm. 4050, tersedia di web http://psycnet.apa.org/journals/ ccp/61/1/40/, diakses: 25 Juli 2014.

7 Faizah Noer Laela, "Konseling Perkawinan sebagai Salah Satu Upaya Membentuk Keluarga Bahagia”, Jurnal Bimbingan dan Konseling Islam, Vol. 02 No. 01, Tahun 2012. Surabaya: Fakultas Dakwah IAIN Sunan Ampel, hlm. 112122.
} 
dari Badan Keluarga Berencana dan Pemberdayaan Keluarga (BKBPP) Kabupaten Purbalingga. Tugas mereka adalah mengoordinir kegiatan penyuluhan KB di desa mereka. Mereka juga pada umumnya menjadi tenaga sukarela pula di bidang kesehatan, sehingga mereka dinamakan sebagai tenaga SKD (Satuan Kader Desa). Pengakuan atas peran mereka ini, karena tidak masuk dalam struktur organisasi, disahkan dengan Surat Keputusan (SK) Kepala Desa, yang sekaligus menjadi "pengikat" hubungan kerja dengan Kepala Unit Pelaksana Teknis/UPT dan PKB.

Pada umumnya kader KB di keempat lokasi penelitian adalah kader "senior", baik dari usia maupun "masa kerja". Kebanyakan dari mereka telah berusia di atas 50 tahun, telah menjadi kader lebih dari 15 tahun serta berpendidikan SMP dan SMA. Bertahannya kaderkader "senior" ini disebabkan sulitnya mencari kader pengganti. Terlebih lagi di wilayah mereka peluang kerja bagi perempuan cukup banyak, baik bekerja di "PT" ataupun di rumah (plasma). Mereka sendiri, di sisi lain, merasakan manfaat dari menjadi kader, misalnya bertambah ilmu, bertambah teman dan mempunyai aktivitas positif. Menjadi kader juga dianggap sebagai upaya untuk mendapatkan pahala.

Besarnya peran kader juga ditemukan oleh Utomo, Arsyad dan Hasmi melalui kajiannya selama tahun 1997-1998 di Provinsi Jawa Tengah dan DI Yogyakarta. ${ }^{8}$ Mereka bertugas mempromosikan KB, mengadakan pertemuan, menyediakan informasi, mengorganisasi pengumpulan dana, membantu tabungan dan kredit, mengumpulkan data serta membantu aktivitas sosial lainnya.

Pada umumnya penyuluhan ini, dalam kaitannya dengan upaya pencegahan KDRT di lokasi penelitian, jarang dilakukan secara khusus. Hal ini dikarenakan mereka menganggap tugas ini tidak ditekankan oleh pihak "atasan" yakni PKB di desa mereka. Penekanan penyuluhannya adalah lebih kepada pemotivasian untuk meng-

Utomo ID, Arsyad SS dan Hasmi EN, "Village Family Planning Volunteers in Indonesia: Their Role in the Family Planning Programme", Journal of Reproductive Health Matters, Vol. 14 No. 27, Tahun 2006, hlm. 73-82, tersedia di website www.rhmjournal.org.uk, diakses tanggal 30 Mei 2010. gunakan alat kontrasepsi jangka panjang seperti steril/IUD dan MOP.

Para kader setempat, berdasar hasil konseling dengan ditambah dengan berbagai faktor lainnya membuat hampir semua pekerja PT saat ini merupakan keluarga kecil yang hanya mempunyai 1-2 anak. Alasannya adalah karena pertimbangan ekonomi dan kesibukan pekerjaan. Pertimbangan ini pula yang juga terjadi di kalangan keluarga-keluarga di perkotaan di Pakistan. ${ }^{9}$ Berdasarkan kajian David dan Olufunmilayo, jejaring sosial menjadi salah satu faktor yang memengaruhi preferensi pasangan tentang KB. Faktor-faktor lainnya adalah faktor sosial budaya, peran gender dan agama. ${ }^{10}$

Sasaran penyuluhan yang biasanya diberikan para kader lebih banyak kepada kelompok istri disebabkan asumsi bahwa KB adalah urusan istri. Kurangnya pendekatan kepada kalangan suami itulah yang diduga menjadi penyebab masih sangat sedikitnya akseptor laki-laki. Pada tahun 2010, dari sejumlah 147.915 akseptor KB di Kabupaten Purbalingga, hanya 4.667 laki-laki yang menjadi akseptor KB (2.917 orang untuk jenis kondom dan 1.750 orang untuk jenis MOP). Hasil wawancara dan diskusi kelompok dengan beberapa istri pekerja "PT" terungkap bahwa saat ini mereka membutuhkan sejumlah informasi tentang KB dalam arti yang lebih luas lagi, di samping informasi tentang kesehatan reproduksi, juga tentang kesetaraan gender dalam keluarga (terutama dari perspektif agama) serta kekerasan dalam rumah tangga/KDRT.

Informasi tentang kesetaraan gender sangat dibutuhkan agar mereka dapat memahami peran dan fungsi antara suami dan istri, agar dapat tercipta hubungan yang harmonis dan sekaligus agar terhindar dari percekcokan. Topik KDRT juga sangat dibutuhkan agar masing-masing suami-istri dapat menghindari kasus ter-

\footnotetext{
9 Hussain S dkk, "Factors Affecting the Family Size and Sex Preference among Christian Families in Urban Areas of Faisalabad (Pakistan)", Journal of Agricultural and Social Science. 1813-2235/ 2007/ 03-1-25-27, Tersedia di http://www. fspublishers.org, diakses 30 Mei 2010.

10 Oladeji David and O. Folaranmi Olufunmilayo, "SocioCultural and Norms Factors Influencing Family Planning Choices among Couples in Ibadan Metropolis, Nigeria". Pakistan Journal of Social Sciences, Vol. 4 Issue: 3, Tahun 2007, hlm. 419-432.
} 
sebut. Dengan bertukarnya peran gender mereka, maka pemahaman tentang hal ini sangat penting agar ketahanan keluarga tetap terjaga.

Kebutuhan tentang penyuluhan KB masih diperlukan, karena masih sering ditemukan ketidakkonsistenan antara pengetahuan tentang KB dengan perilaku, tidak saja di kalangan keluarga miskin ${ }^{11}$, melainkan juga di wilayah perkotaan. ${ }^{12}$ Kebutuhan ini semakin meluas seiring dengan peningkatan permasalahan keluarga. Faktor pendukung lainnya adalah semakin meningkatnya pendidikan suami istri. ${ }^{13} \mathrm{Hal}$ ini juga ditemukan dari kajian Yusra (2002) terhadap wanita nelayan yang menunjukkan adanya pengaruh pengetahuan gizi pada perilaku gizi lainnya. ${ }^{14}$

Kebutuhan penyuluhan KB dalam arti luas tersebut juga muncul di kalangan suami. Berdasarkan hasil wawancara dengan sejumlah suami 'pamong praja" yang diperkuat dengan FGD tampak bahwa selama ini mereka merasa "disingkirkan" dari penyuluhan KB, padahal, mereka pun membutuhkan informasi tentang hal ini dan mereka memiliki forum-forum sosial yang bersifat rutin bulanan (pertemuan tingkat RT dan RW) maupun insidental (misal: kerja bakti) yang bisa menjadi sarana penyuluhannya. Isu-isu yang hampir sama dengan yang dibutuhkan oleh kelompok istri, mereka juga membutuhkan informasi dan keterampilan tentang pemotivasian diri, peningkatan keterampilan hidup (life skills) serta bantuan modal usaha.

Sejumlah kebutuhan informasi yang dirasakan kaum bapak tersebut semakin menegas-

11 Utsman, "Pengetahuan dan Perilaku Reproduksi Sehat Wanita USia Subur (WUS) Keluarga Pra Sejahtera di Desa-desa Tertinggal di Kabupaten Karanganyar Jawa Tengah", Jurnal Pemberdayaan Perempuan, Vol. 2 No. 1 , November 2002, Jakarta: Kementerian Pemberdayaan Perempuan, hlm.7-25.

12 Triyono dan Uminastuti, "Status Kesehatan Reproduksi Wanita Berkeluarga di Palangkaraya", Jurnal Pemberda yaan Perempuan, Vol. 2 No.1, November 2002Jakarta: Kementerian Pemberdayaan Perempuan, hlm. 1-7.

13 Vural BF, dkk, "Factors Affecting Contraseptive Use and Behavior in Kocaeli, Turkey", Journal Advance in Contraceptive, Vol. 15, No. 4, Desember 1999, tersedia di http://www.springerlink.com/content/g7111651184137 02/, diakses 28 Mei 2010.

14 Yusra, "Perilaku Gizi Wania Nelayan Sehubungan dengan Tingginya Prevalensi Busung Lapar di Sumatera Barat", Jurnal Pemberdayaan Perempuan, Vol. 2 No. 1, November 2002, Jakarta: Kementerian Pemberdayaan Perempuan, hlm. 31-42. kan perlunya perluasan makna penyuluhan KB. Penyuluhan KB tidak cukup hanya sekedar memberikan informasi dan memotivasi dari aspek perencanaan jumlah dan jarak kelahiran anak, melainkan harus terus bergerak mengikuti irama kebutuhan dan permasalahan keluarga selanjutnya. Tujuannya adalah membentuk keluarga kecil berkualitas dan berketahanan.

Sebenarnya, perlunya pelibatan laki-laki dalam penyuluhan gender sudah tampak dari komitmen penyuluhan KB berperspektif gender dari BKKBN yang tertuang dalam kebijakan KIE (komunikasi, informasi dan edukasi) responsive gender. Hal yang diperlukan, dengan demikian adalah revitalisasi agar konsep tersebut dapat benar-benar diterapkan, terutama oleh para kader KB yang menjadi pelaku penyuluhan sesungguhnya.

Kesadaran pentingnya pelibatkan laki-la$\mathrm{ki} /$ suami dalam urusan KB juga ditemui di Malawi. Ketidaklibatkannya suami dalam penyuluhan KB telah berkontribusi terhadap rendahnya tingkat partisipasi KB dan tingginya kehamilan beresiko yang disebabkan karena tidak dilibatkannya para suami dalam penyuluhan, padahal justru mereka yang menjadi pengambil keputusan dalam keluarga. Termasuk dalam hal ini adalah penentuan tentang jumlah anak. ${ }^{15}$ Kajian di Turkey, menunjukkan bahwa pelibatan suami dalam urusan KB (terutama penentuan jumlah anak dan metode kontrasepsi yang akan digunakan) dan meningkatnya pendidikan suami berpedan meningkatkan partisipasi KB laki-laki. ${ }^{16}$

\section{Model Penyuluhan KB Berbasis Gender}

Penyuluhan KB adalah kegiatan penyampaian informasi untuk meningkatkan pengetahuan, sikap dan perilaku keluarga dan masyarakat guna mewujudkan keluarga berkualitas. Penyuluhan KB merupakan suatu upaya yang berorien-

15 Kishindo P, "Family Planning and the Malawian Male". Journal of Social Development in Africa, Vol. 9 No. 2, Tahun 1994, hlm. 61-69, tersedia di http://archive.lib. msu/DMC/African\%20Journals/pdfs/social\%20developme nt/vol9no2/jsda0092008. Pdf, diakses 30 Mei 2010.

16 Vural BF, Vural, J. Diker dan I. Yucesoy. 1999. "Factors Affecting Contraseptive Use and Behavior in Kocaeli, Turkey". Journal Advance in Contraceptive, Vol. 15, No. 4, Desember 1999. Tersedia di http://www. Springerlink.com/content/g711165118413702/, diakses 28 Mei 2010. 
tasi jangka panjang dalam upaya mewujudkan keluarga yang berkualitas.

Berdasarkan uraian sebelumnya tampak bahwa proses penyuluhan KB yang pada umumnya dilakukan oleh para Kader KB Desa adalah: pertama, menggunakan pendekatan individual dan kelompok; kedua, memfokuskan sasarannya kepada kelompok istri; dan ketiga, memfokuskan materinya pada KB dalam arti sempit. Penerapan ini tidak terlepas dari arahan dan tugas dari Kepala UPT Kecamatan dan PKB di desa masing-masing yang biasanya diberikan pada saat rakor bulanan di kecamatan dan desa. Hal ini pun tidak terlepas dari kebijakan BKBPP Kabupaten yang juga tidak terlepas dari kebijakan Bupati, BKKBN Provinsi dan KKBN Pusat. Proses penyuluhan ini dapat dilihat pada gambar 1.

Berdasarkan model tersebut tampak bahwa Kader KB-lah yang secara langsung memberikan penyuluhan kepada PUS. PKB, yang sebenarnya merupakan penyuluh formal/resmi, justru tidak/sangat jarang berhadapan langsung dengan PUS. Aktivitas mereka pada umumnya terhenti hanya sampai tahap tingkat Kecamatan dan desa baik pada saat Rakor yang diadakan sebulan sekali maupun kegiatan-kegiatan insidental. Beberapa PKB kadang-kadang mendatangi kegiatan Posyandu yang diadakan sebulan sekali, namun demikian, disebabkan rata-rata mereka membina empat desa (yang berarti jumlah Posyandunya bisa mencapai 25 Posyandu), biasanya kunjungannya dilakukan bergilir.

Terbatasnya materi penyuluhan oleh Kader KB kepada para PUS tidak terlepas dari rendahnya tingkat pendidikan mereka dan terbatasnya pengetahuan tentang issu-issu keluarga. Acara rakor bulanan lebih sering diisi dengan informasi program pelayanan yang akan dilaksanakan yang biasanya berujung pada pemberian tugas, misalnya mencari akseptor dan mendata, kalaupun ada materi yang disampaikan, biasanya hanya disampaikan garis besarnya saja dan mereka diminta mempelajari sendiri materi yang dibagikan. Kondisi ini membuat mereka kurang percaya diri dan kurang mampu untuk meyakinkan PUS agar bersedia mengikuti apa yang diinformasikan, sehingga mereka sangat membutuhkan pemberian materi secara lebih men- dalam dan beragam. Materi-materi yang dibutuhkan tidak jauh berbeda dengan informasi yang dibutuhkan dari perspektif PUS. Pembekalan lainnya yang dibutuhkan adalah tentang teknik pemotivasian, agar lebih mampu meyakinkan PUS. Kurang maksimalnya pembekalan oleh Gambar 1. Model Penyuluhan KB Saat Ini (Existing Model)

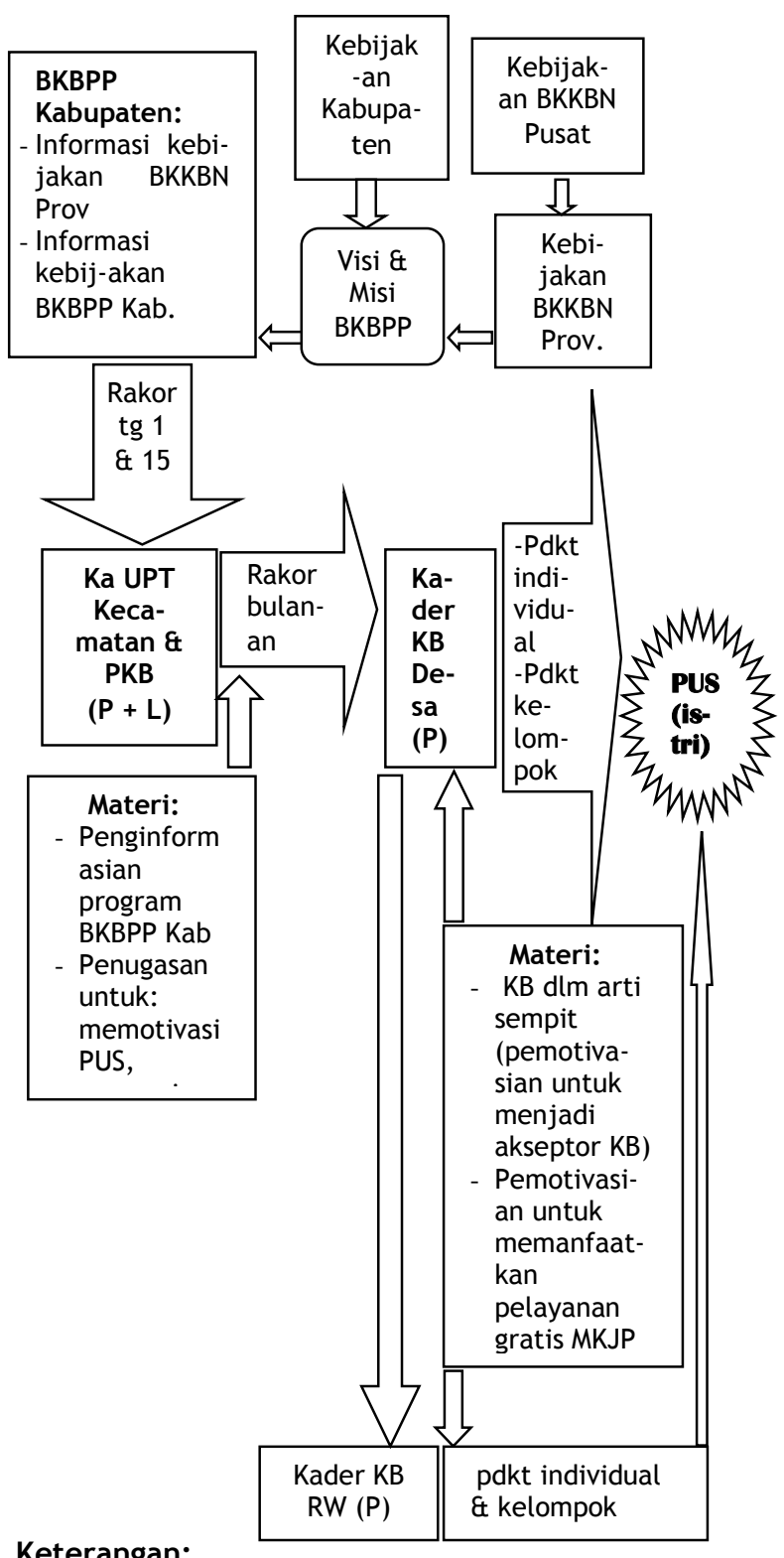

Keterangan:

P: Perempuan; L: Laki-laki

Ka UPT Kecamatan dan PKB disebabkan karena kurangnya pembekalan yang mereka terima dari BKBPP Kabupaten. Rakor bulanan setiap tanggal 1 (diikuti seluruh PKB dan Ka UPT Kecamatan se-kabupaten) dan rakor bulanan tanggal 15 (di 
ikuti UPT Kecamatan se-kabupaten) juga lebih sering menginformasikan kebijakan tingkat kabupaten yang diminta untuk ditindaklanjuti ke masing-masing kecamatan.

Sangat sedikitnya kegiatan pelatihan tersebut tidak terlepas dari keterbatasan anggaran BKBPP. Hal inilah yang antara lain membuat semangat kerja para penyuluh cenderung menurun yang berdampak pada tidak optimalnya proses penyuluhan. Dukungan secara konkrit terhadap para kader baru nampak pada tahun ini (2012) di mana BKBPP memberikan bantuan uang trans-port sebesar Rp30.000,- (potong pajak) yang di-terima tiga bulan sekali.

Dalam kaitannya dengan tuntutan untuk lebih menyertakan kaum laki-laki/kelompok suami dalam proses penyuluhan KB, pada umumnya para informan menganggap bahwa hal tersebut akan lebih mudah dilakukan oleh PKB lakilaki. Kesamaan gender akan memudahkan mereka masuk ke berbagai forum laki-laki yang biasanya diadakan malam hari dan berlangsung hingga larut malam. Demikian halnya untuk pendekatan individual berupa pemotivasian/ konseling, akan lebih mudah dilakukan oleh sesama laki-laki, karena dapat menggunakan bahasa yang sama yang "khas laki-laki".

Pada setiap kecamatan jumlah Ka UPT dan PKB masing-masing empat orang di mana semuanya mempunyai PKB laki-laki, meskipun jumlahnya lebih sedikit (kecuali di Kecamatan Purbalingga yang kesemuanya laki-laki). Berdasarkan hal tersebut, sebetulnya mereka dapat masuk ke dalam forum-forum tersebut untuk memberikan penyuluhan $\mathrm{KB}$, namun demikian, pada umumnya mereka tidak melakukannya.

Sementara itu, semua Kader KB di keempat lokasi penelitian adalah perempuan. Hal ini meneguhkan pandangan bahwa urusan KB dan keluarga adalah urusan perempuan. Padahal, beberapa desa pernah memiliki kader KB Desa laki-laki (dari kalangan aparat) dan hal ini terbukti mampu meningkatkan partisipasi laki-laki menjadi akseptor KB jenis MOP. Semakin banyaknya keluarga yang mengalami peralihan peran gender (tidak saja dari kalangan keluarga yang istrinya bekerja di "PT", melainkan juga dari jenis pekerjaan lain), maka pendekatan pe- nyuluhan yang responsif gender semakin diperlukan, sehingga perlu dilakukan revitalisasi model penyuluhannya yang mencakup tiga aspek.

Pertama, komitmen para pengambil kebijakan. Selama ini keberadaan keluarga "pamong praja" belum mendapat perhatian dari para pembuat kebijakan di instansi-instansi terkait seperti DPRD, BKBPP, Dinsosnakertrans, Disperindagkop serta PKK Kabupaten. Hal ini tampak dari tidak adanya pernyataan kebijakan yang menyinggung hal tersebut, sehingga diperlukan penyadaran di kalangan para pejabat tersebut atas keberadaan keluarga tersebut agar selanjutnya membuat kebijakan yang responsif terhadap kebutuhan dan permasalahan mereka (suami dan istri).

Kedua, sasaran penyuluhan. Sasaran program penyuluhan $\mathrm{KB}$ tidak hanya kaum istri, melainkan juga suami, karena sebuah keluarga dibangun oleh suami dan istri, sehingga proses perencanaan dan perkembangannya pun harus melibatkan kedua pihak ini. Banyaknya suami yang lebih banyak di rumah menjadi peluang untuk lebih menginformasikan issu KB dan keluarga kepada mereka. Hal ini perlu dilakukan, karena biasanya sebagai laki-laki mereka tidak dipersiapkan untuk menjalankan peran domestik. Akibatnya banyak yang tidak bisa menyesuaikan dengan alih peran ini atau bahkan tidak peduli dengan urusan tersebut, padahal, istri idak memiliki banyak waktu untuk mengurus rumah tangga dan anak. Hal ini berakibat, urusan pekerjaan rumah dan pengasuhan anak menjadi berantakan dan hal ini dapat memicu ketidakharmonisan keluarga.

Ketiga, pihak yang terlibat. Penyuluh formal di keempat lokasi penelitian adalah perempuan dan laki-laki dengan jumlah berimbang. Adapun kader KB-nya (yang langsung berhadapan dengan PUS) semuanya adalah perempuan. PKB laki-laki diharapkan dapat lebih aktif masuk ke forum pengurus RT dan RW untuk memberikan pembekalan kepada mereka. Mereka inilah yang selanjutnya diharapkan menjadi "penyambung lidah" kepada kelompok bapak di forum RT masing-masing. Penggerakan laki-laki di semua lini ini diharapkan akan lebih meningkatkan pemahaman kaum bapak tentang KB (dalam arti 
sempit dan luas), sehingga akan meningkatkan kepedulian dan tingkat partisipasi mereka baik secara langsung maupun tidak langsung.

Keempat, materi Penyuluhan. Tujuan program KB adalah membentuk keluarga kecil berkualitas. Untuk mencapai hal tersebut, maka program yang dikembangkan mencakup tiga bidang yakni bidang KB, KS (Keluarga Sejahtera) dan PP (Pemberdayaan Perempuan). Ketiga bidang ini selanjutnya ditindaklanjuti oleh PKB sebagai tenaga penyuluh yang kemudian melibatkan para kader sebagai ujung tombaknya.

Kenyataannya, materi penyuluhan KB telah tereduksi menjadi KB dalam arti sempit, yakni hanya terfokus pada upaya pemotivasian agar para PUS merencanakan jumlah dan jarak kelahiran anak melalui pemakaian alat kontrasepsi (terutama yang termasuk jenis MKJP). Dengan sudah melembaganya nilai-nilai keluarga kecil (rata-rata jumlah anak 2), maka sudah seharusnya topik penyuluhan KB lebih dikembangkan untuk lebih mengarahkan PUS menuju keluarga berkualtas. Seiring dengan meningkatnya keluarga yang mengalami alih peran gender, maka sudah seharusnya materi penyuluhan KB pun menyesuaikan kondisi, kebutuhan dan permasalahan mereka (suami dan istri).

Para penyuluh (terutama para kader KB yang berhadapan langsung dengan masyarakat), oleh karena itu, perlu dibekali materi issu-isu aktual tersebut. Dalam kondisi keterbatasan anggaran, diperlukan strategi "jejaring" dengan pihak-pihak terkait agar bersama-sama meningkatkan kompetensi para penyuluh. Aktif menggalang kerja sama dengan Perguruan Tinggi (baik individu para dosen maupun secara kelembagaan) yang memiliki kewajiban Dharma penelitian dan pengabdian kepada masyarakat diharapkan dapat menjembatani masalah ini.

Pihak lain yang perlu dilibatkan adalah pihak perusahaan rambut di mana ribuan istri bekerja. Banyaknya curahan waktu di "PT" untuk bekerja, maka dapat dilakukan terobosan untuk membuat penyuluhan di tempat kerja dengan menyesuaikan kondisi yang ada. Hal yang terpenting adalah bahwa para istri tidak sama sekali kehilangan kesempatan untuk menambah ilmu terkait dengan peran strategis mereka seba- gai ibu, istri dan anggota masyarakat. Proses revitalisasi penyuluhan KB tersebut dapat diringkas dalam sebuah model sebagai berikut:

\section{Gambar 2. Model Penyuluhan KB Berbasis Gender}

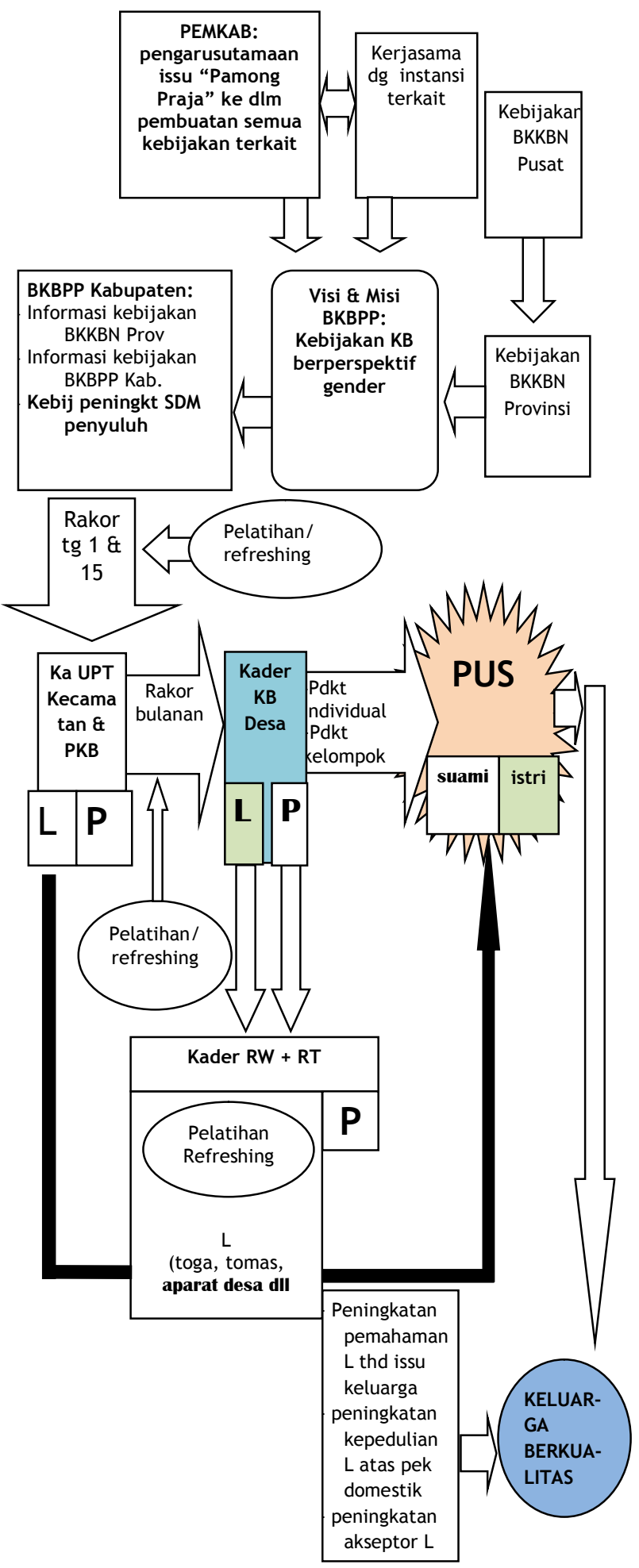




\section{Penutup}

Simpulan

Fenomena keluarga "pamong praja” terjadi di lokasi penelitian di mana para istri bekerja di perusahaan rambut, sedangkan para suami bekerja serabutan, meskipun tampaknya dapat dijalani dengan baik, akan tetapi kondisi ini rentan menimbulkan ketidakharmonisan keluarga yang antara lain berupa KDRT khususnya berupa kekerasan psikis dan seksual. Kenyataannya, keberadaan mereka belum mendapat perhatian dari para pembuat kebijakan terkait. Hal ini tampak dari tidak adanya grand strategy yang dibuat untuk mengatasi hal ini. Penyuluhan KB oleh para kader KB Desa (yang kesemuanya perempuan) belum responsif gender, karena sasarannya masih dominan perempuan dan materinya masih terbatas KB dalam arti sempit (tentang perencanaan jumlah dan jarak kelahiran anak melalui penggunaan alat kontrasepsi), sehingga diperlukan revitalisasi model penyuluhannya agar lebih responsif gender sesuai dengan kondisi, permasalahan dan kebutuhan keluarga setempat.

\section{Saran}

Berdasarkan hasil penelitian tersebut disarankan agar perlu dilakukan penyadaran di kalangan para pejabat terkait atas fenomena ini, agar dibuat kebijakan holistik dan berkesinambungan untuk mengatasi permasalahan ini. BKBPP diharapkan agar: pertama, bekerja sama dengan Perguruan Tinggi untuk memberikan pelatihan kepada para kader KB dan PKB. Materi pelatihannya adalah kesehatan reproduksi, kesetaraan gender (terutama dari perspektif agama), tumbuh-kembang anak serta permasalahan remaja. Kalangan laki-laki/suami perlu diberikan juga materi pemotivasian diri, pelatihan keterampilan dan bantuan modal, agar dapat meningkatkan status sebagai pencari nafkah utama; dan kedua, mendorong pihak perusahaanperusahan rambut untuk menyediakan waktu dan sarana mengadakan penyuluhan KB di tempat kerja.

\section{Daftar Pustaka}

Akbarini, Trie Utami. Iwang Gumilar, Roffi Grandiosa. "Kontribusi Ekonomi Produktif Wanita Nelayan terhadap Pendapatan Keluarga Nelayan di Pangandaran. Kabupaten Ciamis". Jurnal Perikanan Kelautan. Vol. 3 No. 3. Website http://jurnal.unpad.ac.id/jpk/article/view/1421. Diakses tanggal 22 Juli 2014;

Andriati, Retno. "Relasi kekuasaan Suami dan Istri pada Masyarakat Nelayan". Jurnal Masyarakat Kebudayaan Politik. Vol. 21 No. 1. 2010. Surabaya: FISIP Universitas Airlangga;

Babcock. dkk. "Power and violence: The relation between communication patterns, power discrepancies and domestic violence". Journal of Consulting and Clinical Psychology. Vol. 61 No. 1. Februari 1993. tersedia di web http://psycnet.apa.org/ journals/ccp/61/1/40/. Diakses: 25 Juli 2014;

D, Utomo I. Arsyad SS dan Hasmi EN. "Village Family Planning Volunteers in Indonesia: Their Role in the Family Planning Programme". Journal of Reproductive Health Matters. Vol. 14 No. 27. Tahun 2006. Tersedia di website www.rhmjournal.org.uk. Diakses tanggal 30 Mei 2010;

David, Oladeji and O. Folaranmi Olufunmilayo. "Socio-Cultural and Norms Factors Influencing Family Planning Choices among Couples in Ibadan Metropolis. Nigeria". Pakistan Journal of Social Sciences. Vol. 4. Issue: 3. Tahun 2007;

F, Vural B. dkk. 1999. "Factors Affecting Contraseptive Use and Behavior in Kocaeli. Turkey". Journal Advance in Contraceptive. Vol. 15. No. 4. Desember 1999. Tersedia di http://www.springerlink.com/content/g711165118413702/. Diakses 28 Mei 2010;

dkk. "Factors Affecting Contraseptive Use and Behavior in Kocaeli. Turkey". Journal Advance in Contraceptive. Vol. 15 No. 4. Desember 1999. Tersedia di http:// www.springerlink.com/content/g7111651 18413702/. Diakses 28 Mei 2010;

Kusumo, Rani Andriani Budi. Anne Charina. Gema Wibawa Mukti. "Analisis Gender dalam Kehidupan Nelayan di Kecamatan Pengandaran Kabupaten Ciamis". Jurnal Social Economic of Agriculture. Vol. 2. No. 1. April 2013. Pontianak: Fakultas Pertanian Universitas Tanjungpura; 
Laela, Faizah Noer. "Konseling Perkawinan sebagai Salah Satu Upaya Membentuk Keluarga Bahagia". Jurnal Bimbingan dan Konseling Islam. Vol. 02 No. 01. Tahun 2012. Surabaya: Fakultas Dakwah IAIN Sunan Ampel;

Mashud, Mustain. "Perspektif Fenomenologi tentang Trafficking TKW". Jurnal Masyarakat Kebudayaan dan Politik. Vol. 21. No. 2. Tahun 2010. Surabaya: FISIP Universitas Airlangga;

$\mathrm{P}$, Kishindo. "Family Planning and the Malawian Male". Journal of Social Development in Africa. Vol. 9 No. 2. Tahun 1994. Website: http://archive.lib.msu/DMC/African\% 20Journals/pdfs/social\%20development/v ol9no2/jsda0092008. Pdf. Diakses $30 \mathrm{Mei}$ 2010.

$\mathrm{S}$, Hussain dkk. "Factors Affecting the Family Size and Sex Preference among Christian Families in Urban Areas of Faisalabad (Pakistan)". Journal of Agricultural and Social Science. 1813-2235/ 2007/ 03-1-2527. Tersedia di http://www.fspublishers. org. diakses 30 Mei 2010;

S, Wahyu Nugraheni. Tri Marhaeni PA. Sucihatiningsih DWP. "Peran dan Potensi Wanita dalam Pemenuhan Kebutuhan Ekonomi Keluarga Nelayan". Journal of Educational Social Studies. Vol. 1 No 2. Tahun 2012. Tersedia di http://journal.unnes. ac.id/sju/index.php/jess/article/view/73 9. Diakses: 25 Juli 2014;

Triyono dan Uminastuti. "Status Kesehatan Reproduksi Wanita Berkeluarga di Palangkaraya". Jurnal Pemberdayaan Perempuan. Vol. 2 No.1. November 2002. Jakarta: Kementerian Pemberdayaan Perempuan;

Utsman. "Pengetahuan dan Perilaku Reproduksi Sehat Wanita USia Subur (WUS) Keluarga Pra Sejahtera di Desa-desa Tertinggal di Kabupaten Karanganyar Jawa Tengah". Jurnal Pemberdayaan Perempuan. Vol. 2 No. 1. November 2002. Jakarta: Kementerian Pemberdayaan Perempuan;

Yusra. "Perilaku Gizi Wania Nelayan Sehubungan dengan Tingginya Prevalensi Busung Lapar di Sumatera Barat". Jurnal Pemberdayaan Perempuan. Vol. 2 No. 1. November 2002. Jakarta: Kementerian Pemberdayaan Perempuan. 